\title{
DEVELOPMENT OF $e$-XTVT GUIDELINES IN PROMOTING ACTIVE ONLINE LEARNING IN HIGHER EDUCATION: THE FUZZY DELPHI APPROACH
}

\author{
${ }^{1}$ Ramlan Mustapha**, ${ }^{2}$ Mohd Fairuz Jafar, ${ }^{3}$ Asjad Mohamad, ${ }^{4}$ Maziah Mahmud, ${ }^{5}$ Siti Norma Aisyah \\ Malkan, ${ }^{6}$ Surita Hartini Mat Hassan ${ }^{7}$ Rasyad Afif Ibrahim \\ 1,3,4, 5,6,7Universiti Teknologi MARA Pahang, Raub Campus,27600, Raub Pahang, Malaysia, ${ }^{2}$ Universiti Utara Malaysia \\ **Corresponding author: ramlan@uitm.edu.my
}

\begin{abstract}
This study aimed to get an agreement and expert views on the e-xtvt guidelines in promoting active online learning in Malaysia higher education. This study employ Fuzzy Delphi method using a 7 Likert scale to collect responses of 11 experts in various fields of education at public universities in Malaysia. A total of 33 item questionnaire was given to experts for evaluation. Fuzzy Delphi method was used for data analysis. Data were analyzed using triangular fuzzy numbering (triangular fuzzy number) and position (ranking) of each variable is determined using the'defuzzication' process. The findings show that, response and expert consensus on the e-xtvt guidelines in promoting active online learning in higher education are at a good level. The overall findings of the expert consensus agreement exceed $75 \%$, the overall value of the threshold $(\mathrm{d})<0.2$ and a $\alpha$-cut exceeds 0.5 . The priority guidelines elements were sorted by priority and were refined by adding and dropping item as recommended by experts.
\end{abstract}

Keywords:

active online learning, higher education, model development, fuzzy delphi

Article Received: 18 October 2020, Revised: 3 November 2020, Accepted: 24 December 2020

\section{Introduction}

Along with this sophisticated and information literate world, the use of computers, virtual platforms is increasingly needed in line with the rapid development of the ICT world. In today's world of globalization, the internet has become an important medium in all areas of life, especially the world of Education. Access to unlimited information is essential, speed and the need for precise, accurate and unlimited access is becoming a trend in the academic world. The emergence and spread of internet use have a significant impact in the world of Education. The growth of Internet and mobile technology enables people to learn or train through various online platforms. The learning and teaching process are assisted by educational technologies that are used either in the conventional face-to-face classrooms or online e-learning (Zaili, Moi, Yusof \& Hanafi, 2019).

In today's modern world, students need to master various ways of learning in line with the current learning situation. The speed and dominance of technology today makes the need for technology very much needed in the world of Education. Learning has traditionally not been able to match the speed of technology and mastery of online information (Ullah, Nawi, Shahzad, Khan \& Amir, 2017). The technologies are gradually incorporated into a global framework as an intangible, all-encompassing component. The need for virtual learning is also needed, given that access to digital classes, distance learning and accessibility makes online learning more popular and widespread throughout the world (Arasaratnam \& Northcote, 2017).

The advent of new technologies, social media and new learning platforms further simplifies learning patterns. Hence, the Virtual learning technique or OLL is an option. Although the issue of internet access, facilities and facilities are obstacles and challenges, but the OLL process continues to grow rapidly from time to time. Thus, a contemporary educator's challenge is the implementation of online learning, frequently required to teach in both on-campus and online 
learning settings, and acknowledges the importance of socially constructivist theories (Herrington \& Standen, 2000; Swan et al., 2009).

The rapid development of technology-based learning, causing institutions of higher learning to compete to promote and introduce various OLLbased teaching methods. This includes forums, synchronous conversations with tutors and/or students, customized features for online classes, and the use of social media (such as blogs, wikis, Facebook sites), to name a few (Cochrane \& Withell, 2013; Mbati, 2013). The role of social media has also played a role in improving organizational learning in other sectors such as public relations and personal networking (Qi \& Chau, 2016), regulating and empowering communication (Arasaratnam-Smith \& Northcote,2017), or even intimidating governments and organisations (Chandramouli, 2011). The benefits of online courses and online activities and resources have been identified as enhancing learning efficiency, increased participation, and promoting student motivation (Imlawi \& Gregg, 2014).

Since online learning is a very important medium at this time, and there is no specific guideline in formulating the OLL learning curriculum, this study examines and forms a specific guideline that can be adapted or used by educators in designing their OLL learning sessions. Hopefully, this guideline, will be able to fill the gap that exists and add knowledge space in promoting online learning. At the same time, after the Covid-19 pandemic, most institutions of higher learning in Malaysia had to run OLL as a whole. No face to face interaction or class, lecture in the mess classroom. This sudden pandemic opened the eyes of educators in planning to strike OLL in a new norm. Previously, most educators did not care about OLL before causing some of them to run OLL without proper guidelines. Therefore, this study can also to some extent be a guide to educators in planning and implementing OLL following the proper guidelines.
Online learning (OLL)

Online learning (OLL) is a new challenge in the world of education compared to previous methods which are the main medium in teaching (Face to face). The new generation today, is in a sophisticated and fast-moving technology community in line with current technology. The current generation expects a new set of learning norms based on technology, new learning styles and modern methods that are better than the old methods (Arghode, Brieger, \& McLean. 2017). Following the outbreak of the Covid 19 pandemic, shocking educational institutions around the world. This causes most educational institutions to move to alternative teaching to implement learning sessions instead of stopping. As such, OLL is seen to play a very important role in resolving this issue. Although it may be that in the early stages, some did not care about OLL, focusing more on traditional patterned learning, but now, this alternative has become a necessity that needs to be implemented to solve learning problems. Aspects of understanding and teaching methods in OLL previously were not taken into consideration, now have to be faced and understood so that learning sessions can be implemented.

Online learning (OLL) is defined as distance learning based on the use of virtual technology without face to face (Nguyen, 2015). Online learning applies to on-line training, e-learning, online education, internet learning, web-based education, Web training, cyber-learning, computer learning or net-based education (Urdan \& Weggen, 2000). Some people tend to differentiate between the variation of the "absolute" online learning (Oblinger \& Oblinger, 2005), whereas other people simply refer to the technology tool or meaning used in it (Lowenthal, Wilson \& Parrish, 2009). Others display direct connections between modes and online learning that were mentioned above, claiming that one uses the technology used in another (Rekkedal et al., 2003, Volery and Lord, 2000). Most authors define online learning as exposure to learning opportunities using some 
technologies (Benson, 2002, Carliner, 2004, Conrad, 2002). Both Benson, 2002, Conrad, 2002, describe online learning as a more modern form of distance learning that increases access for nontraditional and disenfranchised learners to education. Online education is widely spread in institutions of higher learning around the world rapidly considering its ability to connect students with instructors, peers, materials through a simple, flexible and more user-friendly database (Resse, 2014). Online learning provides a recette of the circumstances for 21 st century learners and the need to collaborate, construct and develop (Green et al 2010).

Online learning began in the 1990s when the Internet became widespread (Ribsaman 2000; Reese 2014). Ribsaman (2000) suggests that there is a distinction between online and distance learning, which is transmission and interaction. $56 \%$ of all 2-4 year-old institutions provide distance educational facilities, while online education is predominantly offered by public institutions and large universities (Waits and Lewis 2003; Allen and Seaman 2006; Reese 2014). This indicates that online education is essential to today's students ' success and that universities should develop programs to meet their students ' needs (Moloney and Oakley 2010).

It is estimated that almost $30 \%$ of higher education enrolment in 2010 was online (Seaman and Allen 2010; Moloney and Oakley 2010; Reese, 2014). Through online education, student diversity is created by creating possibilities for working parents, adult learners and students who have not been able to access traditional classrooms. Online learning (OLL) is becoming increasingly relevant for higher education students who are busy with various assignments, practical activities and so on. In many cases students need to learn and master the field of learning without the need to interact face to face, and submit assignments, tests and so on using virtual tools (Reese, 2014).

\section{Nature of Online learning In Malaysia}

As we all know, the COVID-19 pandemic has a huge impact on educational institutions around the world. The educational atmosphere has stopped for a while due to this problem. This causes the stakeholders in the world of Education to start looking for an alternative method in continuing the Education program. An alternative to this problem is OLL. In particular, Malaysia is no exception to face this problem. The government has issued instructions for all educational institutions to conduct learning sessions using various appropriate platforms, as long as the learning process is carried out. Based on the technology-based environment, OLL is an option by using various platforms such as Webex, Google Meet, Zoom, WhatsApp, Google Classroom and other Education-friendly platforms.

The Government of Malaysia is moving to encourage online education by growing the technological adoption among younger generations and provide affordable and realistic education to tackle the lack of quality education. The government's strong initiative encourages students to enter the online higher education network, which will continue to drive market growth at ever-growing levels (Ullah, Nawi, Shahzad, Khan, \& Aamir, 2017).

The Malaysian National e-learning policy in institutions of higher education refers to the initiative for developing a high quality e-learning system and guidance for the principle of "One Malaysia” (Model Baru Ekonomi-MBE, Malaysia Ministry of Higher Education, 2011). Electronic learning incorporates the main components of elearning, for instance, LMS, content management systems and the management of materials. As education technology evolves, several ICT specialists incorporate new technologies for online learning in the classroom that change the learning environment. Internet technology affects the performance of students and teachers through online networks through which teachers and pupils are linked, as well as between students and learning resources. In addition, e-learning can be 
made available in any time and place by using communication tools such as smartphones by incorporation of learning management systems with mobile learning services (Kassim \& Khalid, 2016).

The Malaysian government has always been positive in encouraging OLLs to be implemented in educational institutions. The Malaysian government has undertaken a national project to connect schools in the virtual learning environment where students and teachers learn and learn. A large allocation is channelled by the government towards developing systems and equipment in implementing this program. More than 10,000 primary and secondary government schools have been fitted with $4 \mathrm{G}$ internet access throughout the nation and a cloud-based interactive learning system called FROG VLE (Campbell, Al Harthi, \& Karimi, 2015; Cheok \& Wong, 2014).

In Malaysia, recent development has seen the launch of the Malaysia Education Blueprint which is a detailed plan of action that maps out the education landscape for the period 2013-2025. Realizing the gap toward producing a more technologically literate workforce, one that is relevant to the 21 st century knowledge and skills, it has identified 11 shifts needed to deliver the change in education outcomes envisioned by all Malaysians. The National Education Blueprint emphasizes effort to leverage ICT to improve the quality of learning across the country. Twentyfive initiatives have been identified under the first wave of the Malaysia Education Blueprint (20132015). One of them includes providing 1BestariNet and software for schools. 1BestariNet is a project led by the Ministry of Education (MOE) to provide access to a cloud based Virtual Learning Environment (VLE) known as the FROG VLE (adopted from the United Kingdom) and high-speed connectivity by June 2014 to all the 10,000 fully-aided government schools. The FROG VLE is a web-based learning platform which provides virtual equivalents of real-world learning (Frog Asia, 2014). Here teachers can assign lessons, tests and marks while students can submit their homework, view their notes and important documents. School administrators can organize their calendars and disseminate notices via FROG VLE. This easy-to-use system allows teachers and students to search for almost anything on the Internet and build it into the site as their educational materials and resources. The FROG VLE provides a plethora of educational resources and cool apps from around the web for easy accessibility during teaching and learning sessions (Cheok \& Wong, 2014).

Apart from that, the Malaysian Ministry of Higher Education also plays an important role in encouraging OLL in the learning process. Most institutions of higher education in Malaysia are encouraged to integrated e learning system, known as Learning Management Systems (LMS), in their courses and face-to-face instruction, creating a 'blended learning' environment for their students (Tayebinik \& Puteh, 2012). The LMS Software is a common method for the design, implementation and management of blended models of education in institutions of higher education (Martinez \& Jagannathan, 2012). LMS, like Moodle and Blackboard, provides resources for online instruction, student-tracking activities including assignment submissions, chat management, group work and other administrative tools (Pellas \& Kazanidis 2015). In the meantime, communications, accompanied by classes, efficiency, quality and administration are the most widely used LMS elements in all Malaysian universities. Nevertheless, there were only a few universities with LMS features that facilitated student engagement, such as community and portfolio (Atan, Embi \& Hussin. 2011).

Based on this scenario, it is clearly seen that educators in Malaysia know how to run OLL. However, researchers have found that most educators carry out teaching activities based on non-standard methods. There is no specific guideline or feature and requirements that need to be used in designing and, implementing OLL. Therefore, the researcher drafted a specific 
guideline to guide educators in explaining the OLL process well based on expert opinion. Based on this existing gap, the researcher devised a guideline that could be a reference for educators in implementing OLL sessions well in the future.

\section{Methodology}

This study specifically uses the Fuzzy Delphi Method (FDM). This study was chosen as it is a unique method to obtain expert consent in determining a concrete decision. This study uses two phases of the formation of the elements of the study questionnaire, namely through the literature review. This study contains two phases of the formation of the elements of the questionnaire, namely, the first phase of the researcher makes a literature analysis in identifying the elements needed in implementing OLL refer to table 1 . The second phase, after all the elements are obtained, the researcher forms an expert questionnaire 7 points and so on are distributed to 11 experts with specific expertise and analysed using Fuzzy Delphi (FDM) technique.

After analysing the literatures, the researcher formulates some elements or guidelines that can be done for educators in implementing OLL. The elements of the guidelines are as follows:

Table 1: OLL guidelines

\begin{tabular}{|c|c|c|}
\hline No & Construct & Guideline elements \\
\hline 1 & $\begin{array}{l}\text { Access and motivation } \\
\text { (Access) }\end{array}$ & $\begin{array}{l}\text { - Built e-activities that enable participant to become } \\
\text { involved and contributed to themselves } \\
\text { - Enable participant to increase their comfort with } \\
\text { the use of technologies } \\
\text { - Provide the pathway for the rest of the interactive } \\
\text { learning process } \\
\text { - Give consent feedback on how learning is } \\
\text { progressing }\end{array}$ \\
\hline & (Motivation) & $\begin{array}{l}\text { - Must have value on learners to succeed. } \\
\text { - Clarify of purpose of activities } \\
\text { - } \text { The need of task that reasonably easily achieve } \\
\text { - Promoting extrinsic or intrinsic motivation }\end{array}$ \\
\hline 2 & On line socialization & $\begin{array}{l}\text { - Creating micro-community through active and } \\
\text { interactive activities } \\
\text { - Creating little cultural experience belonging to the } \\
\text { group } \\
\text { - Establishing strong norm based of trust in each } \\
\text { other's } \\
\text { - Help participants understands the value of working } \\
\text { together } \\
\text { - Developing a shared repertoire include exploring } \\
\text { - Conguage, routines, sensibilities, stories and styles } \\
\text { lantrate of surfacing and exploring viewpoints }\end{array}$ \\
\hline 3 & Information exchange & $\begin{array}{l}\text { - Need the knowledge of tools for remote access to } \\
\text { information and knowledge of strategies for } \\
\text { proposal information retrieval } \\
\text { - Provide direction through the mass of message and } \\
\text { encouragement to start using the relevant material }\end{array}$ \\
\hline
\end{tabular}




\begin{tabular}{|c|c|c|}
\hline & & $\begin{array}{l}\text { - Provide the good structure, pacing \& clear } \\
\text { expectation of participants } \\
\text { Ensure the e activities concentrate on discovering } \\
\text { or exploring aspects of information known to } \\
\text { participants }\end{array}$ \\
\hline 4 & $\begin{array}{l}\text { Knowledge } \\
\text { construction }\end{array}$ & $\begin{array}{l}\text { Critical (analytical) thinking including judging, } \\
\text { evaluating, comparing, contrasting and accessing } \\
\text { - Creative: including discovering, inventing, imaging } \\
\text { \& hypothesizing } \\
\text { - Practical thinking includes applying, using and } \\
\text { practice } \\
\text { - Build the own internal representation of } \\
\text { knowledge, linking directly to personal experience }\end{array}$ \\
\hline 5 & Development & $\begin{array}{l}\text { - Build the ideas acquired through the e activities } \\
\text { and apply them to their individual contexts } \\
\text { - Asking the participants to recall a familiar } \\
\text { experience as a preparation for introducing them to } \\
\text { the new one. } \\
\text { - Revisiting and reconsidering in the way that cannot } \\
\text { happen with more transient verbal conversation }\end{array}$ \\
\hline
\end{tabular}

Sources: Salmon (2002)

\section{Research sampling}

This study uses purposive sampling. This method is most suitable as the researcher wants to get a consensus view and consensus on something. According to Hasson, Keeney \& McKenna (2000) the most appropriate method in FDM is purposeful sampling. Meanwhile, a total of 11 experts were involved in this study. The experts involved are as described in table 2 . The selection of these experts is made based on their experience and expertise in their respective fields. In this study if the expert involved is homogeneous then the required number of specialists is 5-10. Adler
$\&$ Ziglio (1996) the appropriate number of experts in the Delphi method is between 10 to 15 people if there is a level of uniformity (homogeneous). According to Sforza \& Ortolano (1984) stated that the sample for FDM is between 8 to 12 if the sample is Homogenous and is sufficient as well as the opinion of Philip (2000) stated the sample of experts between 7 to 12 . However, the researcher used a total of 11 experts in this study given the difficulty of getting a response from an expert and the lack of time limiting the process of obtaining data. However, 11 expert samples are sufficient to obtain information and expert agreement.

Table 2: expert list

\section{$\begin{array}{lll}\text { Expert list } & \text { Field of expertise } & \text { Institution }\end{array}$}

3 Professors

3 Ass. Professor

3 Senior lecturers

2 Lecturer
Multimedia/ education

Educational technology Public University

Multimedia \& IT

ICT
Private university

\section{Expert criteria}

According to Booker \& Mc Namara (2004), experts are qualified individuals, knowledgeable and have knowledge as a result of training, practice and experience they go through. Specialists are usually identified based on the 
qualifications, training, experience, professional membership, and peer recognition they have earned (Nikolopoulus, 2004; Perera, Drew \& Johnson, 2012). According to (Cantrill, Sibbald \& Buetow, 1996; Mullen, 2003) an expert is any individual who has experience, knowledge related to a particular topic or field. In the Fuzzy Delphi study, the element of expert selection becomes one of the important aspects that need to be considered. Matters arising such as validity, validity and reliability of the results of the analysis and findings can be disputed if the selection of experts is carried out inaccurately and based on certain criteria (Mustapha \& Darusalam, 2017). Basically, the selection of experts and the accuracy of the selection of experts is very important in the method of Delphi or Fuzzy Delphi in determining the quality, accuracy and credibility of the results obtained. According to (Dalkey \& Helmer, 1963; Linstone, 2002) that in order to achieve the meaning, accuracy and quality of Delphi results, research problems, and a survey question must have continuity with the importance, knowledge with the experts involved. Moreover, Kaynak \& Macauley (1984) asserted that every expert involved in the study must represent or be knowledgeable with the field or subject being studied. Based on very strict selection criteria, the researcher selects experts who have 7 years of experience and above and experts who are exactly right with their field of expertise and with respect to the study.

\section{Instrumentation}

The research instrument for Fuzzy Delphi was developed by the researcher based on the study literature. Based on Skulmowski, Hartman \& Krahn (2007) the formation of questionnaire elements by researchers can be formed based on literature, pilot studies and experience. Meanwhile, according to Mustapha \& Darussalam, (2017)) in formulating questions for the Fuzzy Delphi technique based on research highlights, expert interviews and also through focus group techniques. In addition, according to Okoli and Pawlowski (2004) the formation of items and content elements of a study should be done through a literature review related to the scope of study. Therefore, researchers use literature in obtaining the elements of OLL. Then a set of expert questions is formed using a 7-point scale. The selection of the 7-point scale was chosen because the higher the number of scales the more accurate and accurate the data obtained (Chen, Hsu \& Chang, 2011). To make it easier for experts to answer the questionnaire, the researcher has placed a scale value of 1 to 7 to replace the Fuzzy value as shown in Table 4 for the following 7-point linguistic scale:

Table 3: Fuzzy scale

\begin{tabular}{lc} 
Item & Fuzzy Number \\
Strongly Disagree & $(0.0 .0 .0,0.1)$ \\
Disagree & $(0.0,0.1,0.3)$ \\
Somewhat Disagree & $(0.0,0.3,0.5)$ \\
Neither agree or disagree & $(0.3,0.5,0.7)$ \\
Somewhat agree & $(0.5,0.7,0.9)$ \\
Agree & $(0.7,0.9,1.0)$ \\
Strongly agree & $(0.9,1.0,1.0)$ \\
\hline
\end{tabular}

Table 4: Steps in implementing Fuzzy Delphi Method

Step Formulation

1. Expert selection

www.psychologyandeducation.net
- In this study a total of 11 experts were used. A number of experts were invited to determine the importance of the evaluation criteria on the 


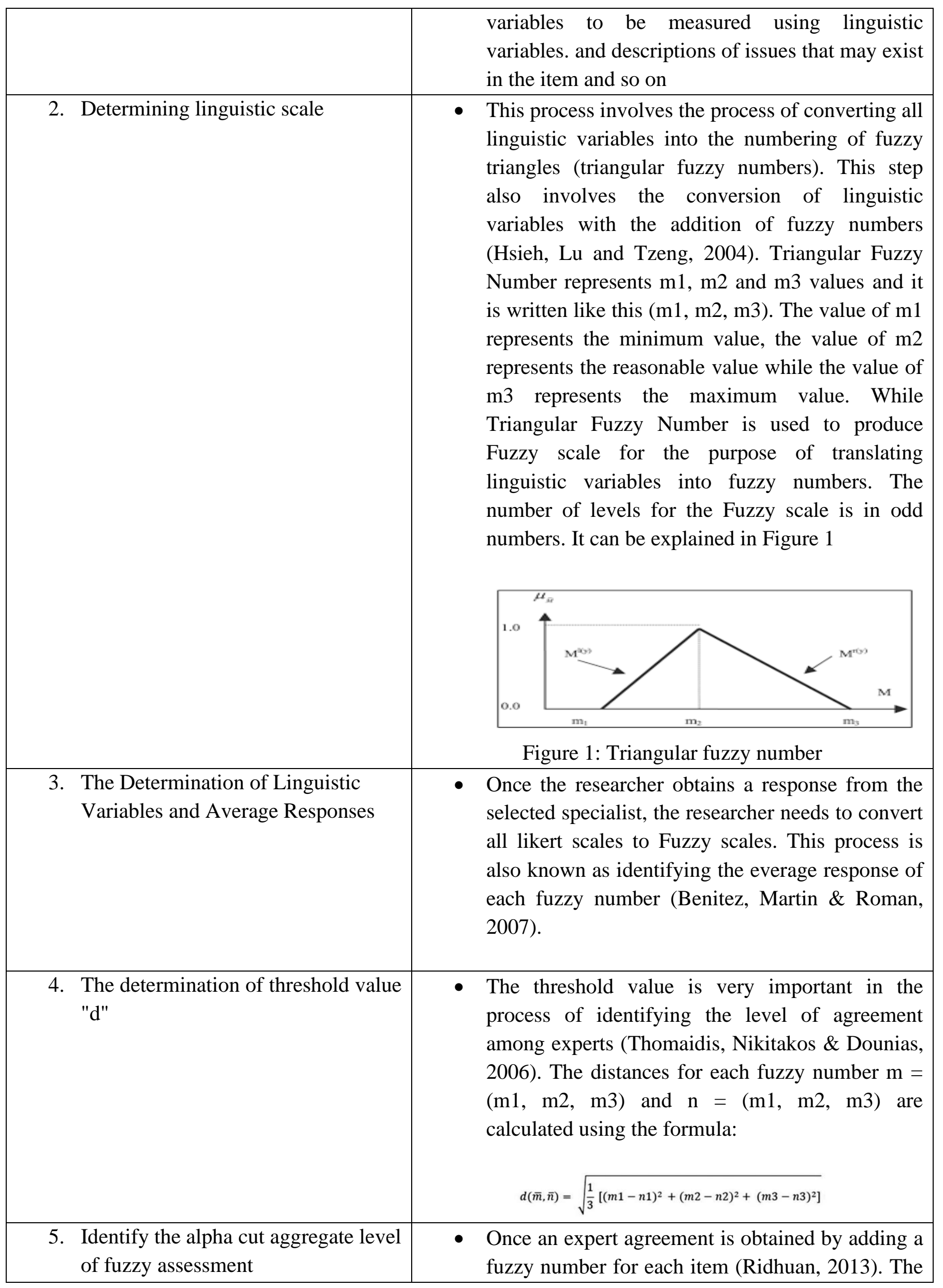




\begin{tabular}{|c|c|}
\hline & $\begin{array}{l}\text { calculation and determination of fuzzy values is } \\
\text { by using the formula: Amax }=(1) / 4(\mathrm{~m} 1+2 \mathrm{~m} 2+ \\
\mathrm{m} 3)\end{array}$ \\
\hline 6. Difuzzication process & $\begin{array}{l}\text { - This process uses the formula Amax }=(1) / 4(\mathrm{a} 1+ \\
2 \mathrm{am}+\mathrm{a} 3) \text {. If the researcher uses Average Fuzzy } \\
\text { Numbers or average response, the resulting score } \\
\text { number is a number that is in the range } 0 \text { to } 1 \\
\text { (Ridhuan et al.2014). In this process, there are } \\
\text { three formulas namely: i. A }=1 / 3 *(\mathrm{~m} 1+\mathrm{m} 2+ \\
\mathrm{m} 3), \text { or; ii. A }=1 / 4 *(\mathrm{~m} 1+2 \mathrm{~m} 2+\mathrm{m} 3) \text {, or; iii. A } \\
=1 / 6 *(\mathrm{~m} 1+4 \mathrm{~m} 2+\mathrm{m} 3) \text {. A-cut value }=\text { median } \\
\text { value for ' } 0 \text { ' and ' } 1 \text { ', where } \alpha \text {-cut }=(0+1) / 2= \\
0.5 . \text { If the resulting A value is less than the } \alpha \text {-cut } \\
\text { value }=0.5 \text {, the item will be rejected because it } \\
\text { does not indicate an expert agreement. According } \\
\text { to Bojdanova (2006) the alpha cut value should } \\
\text { exceed } 0.5 \text {. It is supported by Tang } \& \text { Wu (2010) } \\
\text { who stated that the } \alpha \text {-cut value should be more } \\
\text { than } 0.5 \text {. }\end{array}$ \\
\hline 7. Ranking process & $\begin{array}{l}\text { - The process of positioning is by selecting } \\
\text { elements based on defuzzication values based on } \\
\text { expert agreement where the element with the } \\
\text { highest value is determined by the most important } \\
\text { position (Fortemps \& Roubens, 1996) }\end{array}$ \\
\hline
\end{tabular}

\section{Finding}

In this section, the researcher will present the findings of the study data based on the expert's consensus on the elements or guidelines in formulating the implementation of OLL. The data obtained were based on 11 sets of Fuzzy Delphi questionnaires that were given to 11 experts in the relevant fields. The results of the study are as follows:

Table 5: Finding of expert consensus of the OLL guideline construct

\begin{tabular}{cccccc}
\hline Expert & construct 1 & construct 2 & construct 3 & construct 4 & construct 5 \\
\hline 1 & 0.097 & 0.582 & 0.069 & 0.285 & 0.036 \\
2 & 0.115 & 0.097 & 0.083 & 0.107 & 0.036 \\
3 & 0.097 & 0.097 & 0.069 & 0.107 & 0.036 \\
4 & 0.582 & 0.097 & 0.083 & 0.107 & 0.036 \\
5 & 0.097 & 0.097 & 0.083 & 0.107 & 0.036 \\
6 & 0.296 & 0.097 & 0.069 & 0.285 & 0.036 \\
7 & 0.097 & 0.097 & 0.069 & 0.107 & 0.036 \\
8 & 0.097 & 0.097 & 0.083 & 0.107 & 0.036 \\
9 & 0.097 & 0.296 & 0.069 & 0.107 & 0.356 \\
10 & 0.097 & 0.097 & 0.069 & 0.107 & 0.036 \\
11 & 0.097 & 0.097 & 0.083 & 0.285 & 0.036 \\
\hline
\end{tabular}




\begin{tabular}{|c|c|c|c|c|c|}
\hline $\begin{array}{l}\text { "d" value of } \\
\text { every item }\end{array}$ & 0.161 & 0.159 & 0.076 & 0.155 & 0.065 \\
\hline $\begin{array}{l}\text { average of "d" } \\
\text { value }\end{array}$ & \multicolumn{5}{|c|}{0.123} \\
\hline item below & \multirow[b]{2}{*}{9} & \multirow[b]{2}{*}{9} & & \multirow[b]{2}{*}{8} & \\
\hline$<0.2$ & & & 11 & & 10 \\
\hline $\begin{array}{l}\text { average of } \% \\
\text { item below } \\
\text { than } 0.2\end{array}$ & $82 \%$ & $82 \%$ & $100 \%$ & $72 \%$ & $90 \%$ \\
\hline $\begin{array}{l}\text { Percentage } \\
\text { average }\end{array}$ & \multicolumn{4}{|c|}{$85 \%$} & \\
\hline Defuzzication & 0.900 & 0.900 & 0.912 & 0.894 & 0.942 \\
\hline Ranking & 3 & 3 & 2 & 4 & 1 \\
\hline
\end{tabular}

As a result of data analysis, (refer to table 5), the blackened threshold value exceeds the threshold value $0.2(>0.2)$. This means that there are experts' opinions that are not in line or even and do not reach consensus on certain items. However, the average value of all items of academic dishonesty factors shows a threshold value (d) $<0.2$ which is 0.123 . If the average value of threshold (d) is obtained less than 0.2 , then the item has reached a good expert agreement (Cheng \& Lin, 2002; Chang, Hsu \& Chang, 2011). Meanwhile, the overall percentage of expert agreement is at a value of $85 \%$ agreement which is more than (>
$75 \%$ ) means to meet the conditions of expert agreement on this item. In addition, all Alpha-Cut defuzzication values (average of fuzzy response) exceed $\alpha$-cut $=>0.5$. According to $($ Tang $\& \mathrm{Wu}$, 2010; Bojdanova, 2006)) the alpha cut value should exceed 0.5 and if it is less than 0.5 , then it should be dropped. The findings of this analysis show that the OLL guideline and construct have received good expert agreement. The items agreed upon by the consensus of experts are arranged according to priority (ranking) as shown in table 6. 
Table 6: Final OLL guideline ( $e$-XTVT) based on expert consensus

$\begin{array}{llcc}\begin{array}{l}\text { Previous } \\ \text { rank }\end{array} & \text { New } & \begin{array}{c}\text { Guideline of OLL based } \\ \text { on expert consensus and } \\ \text { Item rank (see the table 5 } \\ \end{array} & \\ & & \text { result) }\end{array}$

\begin{tabular}{|c|c|c|c|}
\hline 5 & 1 & Development & $\begin{array}{l}\text { - Build the ideas acquired through the e activities and } \\
\text { apply them to their individual contexts } \\
\text { - Asking the participants to recall a familiar } \\
\text { experience as a preparation for introducing them to } \\
\text { the new one. } \\
\text { - Revisiting and reconsidering in the way that cannot } \\
\text { happen with more transient verbal conversation }\end{array}$ \\
\hline 3 & 2 & Information exchange & $\begin{array}{l}\text { - Need the knowledge of tools for remote access to } \\
\text { information and knowledge of strategies for } \\
\text { proposal information retrieval } \\
\text { - Provide direction through the mass of message and } \\
\text { encouragement to start using the relevant material } \\
\text { - Provide the good structure, pacing \& clear } \\
\text { expectation of participants } \\
\text { - Ensure the e activities concentrate on discovering or } \\
\text { exploring aspects of information known to } \\
\text { participants }\end{array}$ \\
\hline \multirow[t]{2}{*}{1} & \multirow[t]{2}{*}{3} & $\begin{array}{l}\text { Access and motivation } \\
\text { (Access) }\end{array}$ & $\begin{array}{l}\text { - Built e-activities that enable participant to become } \\
\text { involved and contributed to themselves } \\
\text { - Enable participant to increase their comfort with the } \\
\text { use of technologies } \\
\text { - Provide the pathway for the rest of the interactive } \\
\text { learning process } \\
\text { - Give consent feedback on how learning is } \\
\text { progressing }\end{array}$ \\
\hline & & (Motivation) & $\begin{array}{l}\text { - Must have value on learners to succeed. } \\
\text { - Clarify of purpose of activities } \\
\text { - The need of task that reasonably easily achieve } \\
\text { - Promoting extrinsic or intrinsic motivation }\end{array}$ \\
\hline 2 & 4 & Online socialization & $\begin{array}{l}\text { - Creating micro-community through active and } \\
\text { interactive activities } \\
\text { - Creating little cultural experience belonging to the } \\
\text { group } \\
\text { - Establishing strong norm based of trust in each } \\
\text { other's } \\
\text { - Help participants understands the value of working } \\
\text { together } \\
\text { - Developing a shared repertoire include exploring } \\
\text { language, routines, sensibilities, stories and styles }\end{array}$ \\
\hline
\end{tabular}




\begin{tabular}{|c|c|c|c|}
\hline & & & - Concentrate of surfacing and exploring viewpoints \\
\hline 4 & 5 & Knowledge construction & $\begin{array}{l}\text { Critical (analytical) thinking including judging, } \\
\text { evaluating, comparing, contrasting and accessing } \\
\text { - Creative: including discovering, inventing, imaging } \\
\text { \& hypothesizing } \\
\text { - Practical thinking includes applying, using and } \\
\text { practice } \\
\text { - Build the own internal representation of knowledge, } \\
\text { linking directly to personal experience }\end{array}$ \\
\hline
\end{tabular}

Discussion \& Conclusion

In particular, OLL or according to researchers naming this process as e-XTVT, requires specialized knowledge and good skills in understanding the context of online learning (OLL). The COVID-19 pandemic that erupted was a challenge that greatly affected the learning process. Educators began to think of a method or approach that could be used in implementing the learning process. Although OLL learning has been introduced for a long time, some educators are more comfortable with the old method, causing them to feel stressed with the need for the implementation of learning in the new norm. One of the challenges for them is how best to form online-based activities and learning. Therefore this study to some extent provides guidance to those who are not proficient with OLL.

Based on table 6 , the findings of the study based on expert agreement, formulate a guideline that can be used by educators. An important foundation in the implementation of e-XTVT (OLL) is the development phase which is build the ideas acquired through the e activities and apply them to their individual contexts, asking the participants to recall a familiar experience as a preparation for introducing them to the new one and revisiting and reconsidering in a way that cannot happen with more transient verbal conversation. This is considered a starting point in OLL content that should be used by educators. In the first phase or the initial phase, the educator needs to design or dig out an activity or skill that can attract student's interest so that students' initial perception of learning can be formed well.
The second phase includes information exchange that is need the knowledge of tools for remote access to information and knowledge of strategies for proposal information retrieval, provide direction through the mass of message and encouragement to start using the relevant material, provide the good structure, pacing \& clear expectation of participants, ensure the $e$ activities concentrate on discovering or exploring aspects of information known to participants. In this phase requires the skills of educators in choosing the appropriate form and pattern of teaching. Educators need to use the facilities available in mobilizing students. The need for building a good learning framework, relevant teaching materials, and activities in nurturing students can explore information in a limited environment (Online without face to face).

The third phase is the Access and motivation phase. This phase involves two things namely access containing Built e-activities that enable participant to become involved and contributed to themselves, Enable participant to increase their comfort with the use of technologies, Provide the pathway for the rest of the interactive learning process, Give consent feedback on how learning is progressing. Meanwhile the second part is motivations contains: Must have value on learners to succeed, Clarify of purpose of activities, The need of task that reasonably easily achieve and Promoting extrinsic or intrinsic motivation.

The next phase is Online socialization which contains Creating micro-community through active and interactive activities, Creating little cultural experience belonging to the group, 
Establishing strong norm based of trust in each other's, Help participants understands the value of working together, Developing a shared repertoire include exploring language, routines, sensibilities, stories and style, Concentrate of surfacing and exploring viewpoints. This phase requires educators to plan activities that form socialization based on interactive activities. At the same time the process of isolation through this activity is able to inspire the spirit of belonging, cooperation in groups and focus on the proliferation of ideas together through the process of socialization.

The last phase based on expert consensus is knowledge constructions. At this level the educator have to create, Critical (analytical) thinking including judging, evaluating, comparing, contrasting and accessing, Creative: including discovering, inventing, imaging \& hypothesizing, Practical thinking includes applying, using and practice and Build the own internal representation of knowledge, linking directly to personal experience. At this stage, educators play a role in planning something that can shape students' knowledge. Activities that can improve critical thinking skills, compare differences, be creative and be able to make judgments about things. All these things are very important in shaping the ability of students who are skilled and capable in using limited resources and space without face to face.

Guideline for future research

This study was basically conducted based on literature highlights and expert consensus on the components of OLL implementation. Thus, future researchers may be able to evaluate and explore in more detail through expert interviews in the field related to this OLL, so that the elements of OLL implementation can be improved. Therefore, a qualitative approach or exploration can be utilized in the future. In addition, this study focuses on literature highlights and expert consent as respondents of the study. Future studies may be able to use other methods by adding respondents and a broader study context suggesting this OLL across various curricula and fields. Future studies can also form a specific module based on the output of this study. Maybe with the construction of a special module later will be a specific reference manual for educators in shaping and planning their lessons.

\section{Reference}

[1] Atan, H., Embi, M. A., \& Hussin, S. (2011). E-Learning Policy in Malaysian Higher Education Institutions. In $e$ Learning in Malaysian Higher Education Institutions: Status, Trends, \& Challenges.

[2] Adler, M., \& Ziglio, E. (1996). Gazing into the Oracle: The Delphi method and its application to social policy and public health: Jessica Kingsley Publisher.

[3] Arasaratnam-Smith, L. A., \& Northcote, M. (2017). Community in online higher education: Challenges and opportunities. Electronic Journal of E-Learning.

[4] Arghode, V., Brieger, E. W., \& McLean, G. N. (2017). Adult learning theories: implications for online instruction. European Journal of Training and Development.

https://doi.org/10.1108/EJTD-02-20170014

[5] Bodjanova, S. (2006). Median alphalevels of a fuzzy number. Fuzzy Sets and Systems,157(7), 879-891. doi: 10.1016/j.fss.2005.10.015

[6] Booker, J. M., \& McNamara, L. a. (2004). Solving black box computation problems using expert knowledge theory and methods. Reliability Engineering \& System Safety, 85(1-3), 331-340.

[7] Cantrill, J. a., Sibbald, B., \& Buetow, S. (1996). The Delphi and nominal group techniques in health services research. International Journal of Pharmacy Practice, 4(2), 67-74.

[8] Chandramouli, R. (2011). Emerging social media threats: Technology and policy perspectives. 2011 2nd Worldwide Cybersecurity Summit, WCS 2011. 
[9] Chang, P.-L., Hsu, C.-W., \& Chang, P.-C. (2011). Fuzzy Delphi Method for evaluating hydrogen production technologies. International Journal of Hydrogen Energy, 36(21), 14172-14179. doi:10.1016/j.ijhydene.2011.05.045

[10] Cheok, M. L., \& Wong, S. L. (2014). Teachers' perceptions of E-learning in Malaysian secondary schools. Proceedings of the 22nd International Conference on Computers in Education, ICCE 2014.

[11] Chang, P.-L., Hsu, C.-W., \& Chang, P.C. (2011). Fuzzy Delphi method for evaluating hydrogen production technologies. International Journal of Hydrogen Energy, 36(21), 14172-14179. doi:10.1016/j.ijhydene.2011.05.045

[12] Cochrane, T., \& Withell, A. (2013). Do 21 st century students dream of electric sheep? a mobile social media framework for creative pedagogies. 30th Annual Conference on Australian Society for Computers in Learning in Tertiary Education, ASCILITE 2013.

[13] Green, N. C., Edwards, H., Wolodko, B., Stewart, C., Brooks, M., \& Littledyke, R. (2010). Reconceptualising higher education pedagogy in online learning. Distance Education.

https://doi.org/10.1080/01587919.2010.513 951

[14] Dalkey, N., \& Helmer, O. (1963). An Experimental Application of the Delphi Method to the Use of Experts. Management Science.

[15] Hasson, F., Keeney, S., \& McKenna, H. (2000). Research guidelines for the Delphi survey technique. Journal of Advanced Nursing. $\quad$ https://doi.org/10.1046/j.13652648.2000.t01-1-01567.x

[16] Herrington, J., \& Standen, P. (2000). Moving from an instructivist to a constructivist multimedia learning environment. Journal of Educational Multimedia and Hypermedia.
[17] Hole, Y., \& Snehal, P. (2019). Challenges and solutions to the development of the tourism and hospitality industry in India. African Journal of Hospitality, Tourism and Leisure. 8 (3), 1-11

[18] Hole, Y., \& Snehal, P. \& Bhaskar, M. (2018). Service marketing and quality strategies. Periodicals of engineering and natural sciences, 6 (1), 182-196.

[19] Imlawi， J., \& Gregg, D. (2014). Engagement in Online Social Networks: The Impact of Self-Disclosure and Humor. International Journal of Human-Computer Interaction.

https://doi.org/10.1080/10447318.2013.839 901

[20] Kasim, N. N. M., \& Khalid, F. (2016). Choosing the right learning management system (LMS) for the higher education institution context: A systematic review. International Journal of Emerging Technologies in Learning. https://doi.org/10.3991/ijet.v11i06.5644

[21] Kaynak, E., \& Macaulay, J. A. (1984). The Delphi technique in the measurement of tourism market potential. Tourism Management, 5(2), 87-101.

[22] Linstone, H. A., \& Turoff, M. (2002). The Delphi Method - Techniques and Applications. The Delphi method Techniques and applications.

[23] Lowenthal, P. R., Wilson, B. G., \& Parrish, P. (2009). Context matters: A description and typology of the online learning landscape. 32nd Annual Proceedings: Selected Research and Development Papers Presented at the Annual Convention of the Association for Educational Communications and Technology. https://doi.org/10.1111/j.15325415.1974.tb02175.x

[24] Martinez, M. \& Jagannathan, S. (2012). Learning solution: Moodle: A low-cost solution for successful e-learning. 
Retrieved

from

http://www.learningsolutionsmag.com/artic les/71/moodlealow-cost-solution-for-

successful-e-learning

[25] Moloney, J. F., \& Oakley, B. (2010). Scaling online education: Increasing access to higher education. Journal of Asynchronous Learning Network. 14(1), 55-70.

https://doi.org/10.24059/olj.v14i1.1639

[26] Mbati, L. (2013). Online social media applications for constructivism and observational learning. International Review of Research in Open and Distance Learning. https://doi.org/10.19173/irrodl.v14i5.1579

[27] Mustapha, R, \& Darusalam, G. (2017). Aplikasi kaedah Fuzzy Delphi dalam Kajian Sians Sosial. Penerbitan Universiti Malaya. Kuala Lumpur

[28] Ministry Of Higher Education Malaysia, (2011). "Dasar E-Pembelajaran Negara Institusi Pengajian Tinggi," 2011.

[29] M. A. Embi (2010). Amalan, Keberkesanan \& Cabaran Pelaksanaaan EPembelajaran Di IPT Malaysia, 1st ed, Putrajaya, Malaysia: Jabatan Pengajian Tinggi, Kementerian Pengajian Tinggi Malaysia. 2010.

[30] Nguyen, T. (2015). The Effectiveness of Online Learning: Beyond No Significant Difference and Future Horizons. MERLOT Journal of Online Learning and Teaching.

[31] Nikolopoulos, K. (2004). Elicitation of expert opinions for uncertainty and risk. International Journal of Forecasting (Vol. 20).

[32] Pellas, N., \& Kazanidis, I. (2015). On the value of Second Life for students' engagement in blended and online courses: A comparative study from the Higher Education in Greece. Education and Information Technologies. https://doi.org/10.1007/s10639-013-9294-4
[33] Perera, A. H., Drew, C. A., \& Johnson, C. J. (2012). Expert Knowledge and Its Application in Landscape Ecology. Springer, New York, 1-11. http://doi.org/10.1007/978-1-4614-1034-8

[34] Philip, R.(2000). New Application for Delphi Technique, Annual "San Diego" Pfeifer \& Company, Vol 2, 191-196

[35] Oblinger, D., \& Oblinger, J. (2005). Is It Age or IT: First Steps Toward Understanding the Net Generation. In Educating the Net Generation.

[36] Reese, S., A. (2014). Online learning environments in higher education: Connectivism vs. dissociation. Educ Inf Technol. DOI 10.1007/s10639-013-9303-7

[37] Rekkedal, S. Qvist-

Eriksen, D. Keegan, G.Ó. Súilleabháin, R. Coughlan, H. Fritsch. (2003). Internet based e-learning, pedagogy and support systems NKI Distance Education, Norway

[38] Ribsaman, M. (2000). What is distance education? Defining the concepts and terms which have characterized the field.Retrieved from http://www.distance educator.com/index1a101600.

[39] J. Skulmoski, G., T. Hartman, F., \& Krahn, J. (2007). The Delphi Method for Graduate Research. Journal of Information Technology Education: Research. https://doi.org/10.28945/199

[40] Sforza, V. C., \& Ortolano, L. (1984). Delphi forecasts of land use: Transportation interactions. Journal of Transportation Engineering.

https://doi.org/10.1061/(ASCE)0733-

947X(1984)110:3(324)

[41] Tayebinik, M., \& Puteh, M. (2012). Blended Learning or E-learning? International Magazine on Advances in Computer Science and Telecommunications, 3(1), 103-110

[42] Tang, C. W. \& Wu. C. T. (2010). Obtaining a picture of undergraduate 
education quality: A voice from inside the university. Higher Education, 60, 269-286.

[43] Qi, C., \& Chau, P. Y. K. (2018). Will enterprise social networking systems promote knowledge management and organizational learning? An empirical study. Journal of Organizational Computing and Electronic Commerce. https://doi.org/10.1080/10919392.2018.140 7081

[44] Ullah, A., Mohd Nawi, N., Shahzad, A., Khan, S. N., \& Aamir, M. (2017). An Elearning System in Malaysia based on Green Computing and Energy Level. JOIV : International Journal on Informatics Visualization. https://doi.org/10.30630/joiv.1.4-2.63

[45] Waites, T., \& Lewis, L. (2003). Distance education at degree-granting postsecondary institutions 2000-2001. Washington: U.S. Department of Education, National Center for Educational Statistics.

[46] Zaili, N., Moi, L. Y., Yusof, N. A., Hanfi, M. N., \& Suhaimi, M. H. (2019). The factors of satisfaction on e-learning usage among universiti malaysia kelantan students. Journal of Information System and Technology Management. 